\title{
Bantuan IGGI dan Defisit Neraca Transaksi Berjalan .
}

\author{
Oleh : Suwarsono
}

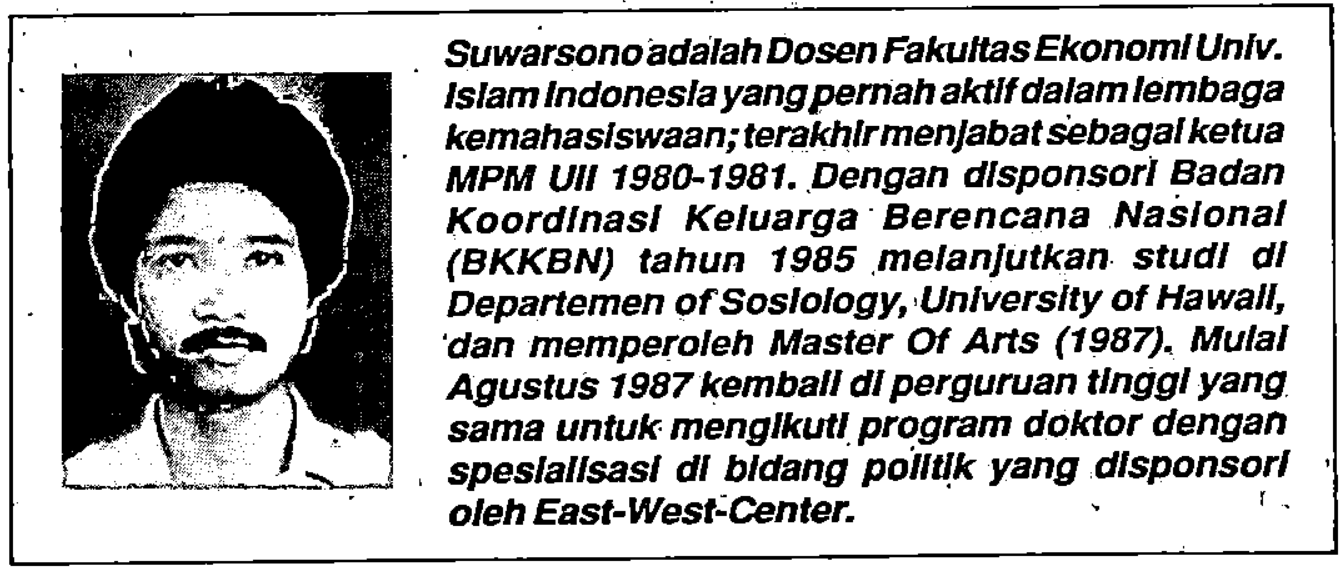

Melegakan dan sekaligus mengejutkan. Itulah kira-kira frasa yang cukup pas untuk menggambarkan makna ekonomis dan politis dari bantuan IGGI yang diterima Indonesia untuk tahun 1991/1992.

Melegakan ? Bagaimana tidak ? Karena seluruh permintaan bantuan dana pinjaman yang diajukan Indonesia temasuk bantuan yang dapat dengan cepat dicairkan (fast disbursing assistence/FDA) dipenuhi. Bahkan, pada saat yang sama Indonesia juga akan menerima bantuan pinjaman dengan format FDA dari Bank Exim Jepang (BEJ).

Indonesia hendak menerima total bantuan sebesar US $\$ 4,75$ milyar dari IGGI, US \$ 1 milyar yang diantaranya berupa FDA. Ini merupakan jumlah terbesar yang pemah diterima Indonesia, sejak berdirinya IGGI tahun 1967. Indonesia juga akan menerima dana sejumlah US \$0,5 milyar dari BEJ. Jika dirupiahkan, dengan asumsi bahwa US $\$$ 1 sama dengan Rp 3000,-, maká jumlah total yang US $\$ 5,35$ milyar tersebut sama dengan Rp 10,5 trilyun. Sebuah jumlah yang amat besar, kelihatannya.

Oleh karena itu, tidak heran jika kemudian-komitmen. IGGI tersebut ditafsirkan sebagai indikator yang jelas. dari kepercayaan dunia, khususnya negara-negara donor dan lembaga keuangan intemasional yang tergabung dalam 'IGGI, terhadap cara-cara yang digunakan oleh Indonesia dalam mengelola hutang luar.negerinya. "Aset yang sangat berharga". 
Setidaknya sampai dengan hari ini, nampaknya IGGI memberikan penilaian yang positif tèrhadap penggunaan dana yang dipinjamkan. Indonesia merupakan "good boy" baik dalam pemilihan sektor dan bidang sasaran' maupuan dalam memenuhi kewajibannya. Indonesia hampir selalu mengikuti "petunjuk" kebijaksanaan si pemberi hutang. Disaat yang sama juga merupakan negara yang selalu mengangsur hutang pokok beserta bunganya dengan tertib dan lancas. Belum pernah mencoba untuk mengajukkan pemudahan pembayaran, apalagi berusaha "ngemplang" hutang, seperti yang dicoba dan 'telah dilakukan oleh negara berkembang lainnya. Melegakan.

Jika ditafsirkan dengan agak luas, maka kesediaan IGGI untuk tetap memberikan bantuạn, termasuk bantuan lunaknya yang berwujud FDA itu, merupakan satu bukti riil bahwa pembangunan ekonomi Indonesia cukup berhasil. Selama tiga tahun berturut-turut sejak tahún 1988 sampai dengan tahun yang lalu, ekonomi Indonesia tumbuh disekitar angka $7 \%$ per tahunnya.

Lebih dari itu, akibat deregulasi moneter yang dengan deras dialirkan iklim investasi menjadi amat kondusif. Komitmen investasi (intended invesment) dan tingkat investasi yang direlisasikan (realized invesment) mengalami lonjakan. Indonesia juga dinilai berhasil dalam meningkatkan peran swasta dalám menunjarig pembangunan ekonominya. Tak kalah hebatnya, ekoniomi Indonesia ternyata juga cukup mampu bertahan dari goncangan ekonomi dunia. Oleh karena itu, hampir tak ditemukan alasan untuk tak meneruskan keseluruhan paket deregulasi (baca :- liberalisasi) ekonomi yang nampaknya memang hendak tẹrus menggelinding.

Yang tak kalah pentingnya, Indonesia juga dikatakan sebagai negara yang berhasil dalam mengatasi persoalan kemiskinan. Kemiskinan absolut berkurang, sekalipun mungkin ketimpangan sosialnya meningkat secara relatif. Jumlah orang yang miskin jauh berkurang, "hanya" tinggal 30 juta orang. Itulah kira-kira, pujian yang kita dengar selama sidang. IGGI tengah berlangsung. Melegakan. Bagaimana tidak ? Hanya soal lingkungan saja yang sedikit mendapat sorotan.

Yang diartikan melegakan ini akan menjadi bertambah, jika kita bersedia sejenak untuk melihat peta geografis ekonomi dunia. Dunia telah berubah. Radikal. Kini, tidâk hanya Indonesia, Asia Tenggara atau Asia saja yang memerlukan dana. Belahan bumi yang lain juga sedang merengek menunggu. Amerika Latin sudah pasti termasuk dalam antrian panjang ini, sementara kini Afrika juga tak mau ketinggalan. Mendesakkan diri. Bahkan Eropa Timur, Uni Soviet dan Timur Tengah. Oleh karena itu, jika dalam situasi demikian panjangnya antrian calon konsumen yang menunggu, kemudian IGGI masih dengan gembira membantu . Indonesia, dengan memenuhi seluruh permintaan Indonesia termasuk "pinjaman lunák" FDAnya, maka apalági kalau bukan kata "syukur" yàng perlu diucapkan. Sekali lagi, bagaimana tidak melegakan?

Lantas apa yang mengejutkan? Paling tidak membuat sebagian kita terpaksa : . ${ }^{\prime}$ mengerutkan dahi. Bagaimana tidak' ? Sekalipun bantuan luar negeri másih tetap dinyatakan sebagai pelengkap, namun, datangnya bantuan IGGI itu mau tak mau 
juga berarti bertambahnya hutang Indonesia. Yang pada gilirannya nanti menjadi beban rakyat. Sampai dengan Desember 1990, pinjaman luar negeri Indonesia mencapai US $\$ 42$ milyar, diluar bantuan IGGI yang baru itu. Sementara pinjaman luar negeri yang dilakukan pihak swasta sebesar kurang lebih US \$9 milyar, belum termasuk derasnya pinjaman swasta yang mengalir pada tahun-tahun pertama 1991 ini. Diperkirakan sampai dengan saat ini total pinjaman luar negeri pemerintah dan swasta tak kurang dari US $\$ 70$ milyar. Jika dirupiahkan, kurang lebih sama dengan Rp 140 trilyun. Kirakira sama dengan setengan kali RAPBN. Sebuah jumlah yang memang telah mendesak untuk dipikirkan dengan lebih cermat dan sungguh-sungguh.

\section{Bagaimana tidak ?}

Yang menjadikan lebih terkejut lagi, ternyata bantuan IGGI yang berupa FDA itu hendak digunakan untuk mengatasi kesulitan (baca:defisit) neraca transaksi berjalan (NTB)/current account/CA). Beban berat yan'g menimpa NTB ini terjadi sebagai akibat besamya defisit pada neraca jasa (NJ) dan neraca modal (NM). Ketiga komponen NTB yakni neraca perdagangan (NPd), neraca jasa (NJ), dan.neraca modal (NM) tak berjalan seiring. Neraca Pembayaran (NP) memang hampir selalu positif, tetapi itu hanya terjadi karena adanya aliran modal masuk karena utang dan sebab lainnya yang lebih besar dibanding keluar (neraca modal surplus). Dalam konteks ini surplusnya $\cdot N M$ tak dapat dibanggakan.

Selama empat tahun ini, sejak tahun 1987 NPd Indonesia aman-aman saja. Bahkan sepanjang usia Orde Baru, saya kira surplusnya jauh lebih banyak . dibanding defisitnya. Apalagi setelah periode stabilisasi ekonomi akhir 1960an dan awal 1970an terlampaui. Artinya di pasar barang (good market) ekonomi Indonesia sudah dapat bertanding, apalagi ketika kemudian ekspor non migas telah mémiliki peran yang lebih besar dibanding dengan ekspor migasnya. Ekspor barang hampir selalu masih lebih besar dari impor. Dari tahun 1988 sampai dengan tahun 1990 NPd selalu surplus, demikian juga padisa tahun 1991. Hal yang sama juga akan terjadi - saya kira - untuk triwulan pertama tahun 1992. Ini dapat terjadi terutama karena ekspor non migas mengalami peningkatan yang pesat, yakni 40 . \% untuk 1987/1988, $30 \%$ untuk $1988 / 1989$ dan $30 \%$ untuk tahun 1989/1990, sekalipun peningkatan tersebut selalu menurun secara relatif. Ada "decreasing growth".

Namun demikian ini juga tak kemudian berarti bahwa untuk tahun-tahun mendatang. NPd akan selalu aman. Peningkatan ekspor non migas sesungguhnya terjadi dalam jumlah prosentase yang semakin kecil.'Celakanya, hal tersebut sepertinya akan berlanjut untuk tahun 1992/1993, sehingga sejak tahun tersebut sepertinya ekonomi Indonesia mulai ditandai oleh pelepasan (slow down) dari peningkatan ekspor non migas. Hal ini menjadi lebih mengkhawatirkan - paling tidak untuk jangka waktu pendek - jika naiknya impor barang modal yang mulai deras sebagai akibat deregulasi ekonomi berlanjut terus, sementara disisi lain investasi tersebut khususnya investasi baru - belum dapat dengan segera menghasilkan devisa.

Hal yang menggembirakan pada amannya NPd - setidaknya sampai dengan , 
saat ini - ternyata tak terjadi pada NJ dan NM.

Akibatnya NTB mengalami defisit. Disamping karena menununnya ekspor non migas dan naiknya impor barang modal, defisit NTB ini terjadi karena runyamnya neraca jasa (NJ). Krisis dan Perang Teluk nampaknya bertanggung jawab terhadap runtuhnya neraca jasa (NJ). Rencana penerimaan devisa dari sektor pariwisata, penerimaan "remittances" dari tenaga kerja Indonesia ýang berada di luar negeri, dan dari sektor perhubungan udara menjadi terganggu. Sementara disaat yang sama pembayaran jasa yang kita lakukan juga terus membengkak. Ekonomi Indonesia di . "faktor market" belum mampu sepenuhnya mendukung kebutuhan pertumbuhan ekonomi. Selama tahun 1990/1991 NTB mengalami defisit sebesar US \$3,8 milyar, sedangkan untuk tahun 1991/1992 diperkirakan mencapai jumlah sebesar US $\$ 4,399$ milyar. Untuk tahun 1992/1993 defiti NTB ini hanya berkurang sedikit dan diperkirakan akan berjumlah US $\$ 4,343$ milyar.

Yang menjadikan lebih terkejut lagi ternyata NM Indonesia' juga memiliki persoalan yang tak kalah peliknya dibanding dengan yang dialami $-\mathrm{NJ}$. Sekalipun utang pemerintah dan utang swasta meningkat, tetapi disisi lain beban angsuran hutang dan bunga juga semakin meningkat dengan lébih pesat. Dalam tahun ini ekonomi Indonesia mengalami "drainage cashflow". Jumlah hutang dan bunga yang dibayarkan kembali temyata lebih besar dari pada jumlah bantuan dana yāng diterima. Sebuah persoalan yang tak dapat lagi ditangani dengan sambil lalu. Dalam tahun 1991/1992 ini jumlah angsuran hutang luar negeri dan bunga yang harus dibayar yang tertera dalam
RAPBN berjumlah sebesar Rp 14.129.5 milyar (lebih dari Rp 14,1 trilyun), sementara dipihak lain jumlah bantuan yang diterima hanya sebesar $\mathrm{Rp}$ 10,5 trilyun. Ini berarti terjadi "capital cutflow" sebesar lebih dari 3,6 trilyun. Yang demikian sesungguhnya telah terjadi sejak beberapa tahun yang lalu, yakni disekitar tahun 1985.

Dengan kata lain, sesungguhnya persoalan neraca pembayaran (NP) - yang surplus karena adanya kewajiban untuk mendatang modal yang lebih besar guna menutup defisit NTB dan "capital cutflow" dari pembayaran hutang - bukan saja tergantung pada defisit tidaknya NTB, tetapi juga pada persoalan NMnya. Ini berarti bahwa jika dikaitkan dengan beban neraca pembayaran sesungguhnya besarnya bantuan yang diterima tahun ini dari IGGI dan BEJ "tak nampak kelihatan besar". Malahan terasa kurang. Paling tidak juga dilihat dengan dimensi waktu yang pendek. Untuk menjaga surplus yang ada pada NP masih diperlukan tambahan sumber dana yang lain, sampai mencapai jumlah sebesar kurang lebih US $\$ 8,7$ milyar. Separoh diantaranya untuk menutup defisit NTB, separoh yang lain untuk mengimbangi hutang pokok dan bunganya.

Dalam jangka panjang, jika semuanya ini berlanjut terus, maka rasanya sulit untuk mengatakan bahwa bantuan luar negeri selamanya hanya akan jadi pelengkap. Nampaknya selama ketiga komponen NTB masih belum berjalan seiring, rasanya susah untuk mengatakan bahwa kebutuhan pinjaman tak mengalami perubahan status, sekalipun mungkin masih terlalu dini untuk mengatakan bahwa hal tersebut merupakan indikator lahimya situasi ketergantungan. 
Terkecuali jika pemerintah memaksa untuk mélakukan mobilitas' dana dari dalam negeri, khususnya dari intensifikasi dan ekstensifikasi pajak, yang sekarang ini tengah gencar-gencarnya dilaksanakan. Namun demikian adalah kemudian alternatif ini akan dapat dèngan segera menjadikan situasi ketergantungan pada hutang luar negeri berubah menjadi mitos belaka ? Harapannya memang demikian, setidaknya karena kini jumlah hutang yang diharapkan 'diterima semakin kecil, sekalipun mungkin ini karena terpaksa dan dipaksa oleh situasi ekonomi intemasional.

Inilah sebuah perșoalan klasik dari negara berkembang (NSB). Sejak dasawarsa pertama pembangunan ekonomi NSB dikumandangkan secara formal oleh PBB ditahun 1960an, persoalan defisit NTB selalu menjadi primadona dan latent. Punya potensi untuk selálu muncul kembali. Dan ternyata, sekarang, setelah kurang dari tiga dasawarsa, "Orde Ekonomi" masih bergelut dengan persoalan yang sama. Diśinilah letak mengejutkannya.

Bagaimana tidak ?

Demikianlah arti bantuan IGGI. Melagakan sekaligus mengejutkan. Sudah meningkat tetapi masih kurang besar. Jika terus membesar, maka bukan mustahil, jika, statusnya sebagai pèlengkap akan berubah. Besar memang enak dan melegakan, bahkan mengasyikan, kecuali untuk urusan hutang. Jika anda tak percaya, silahkan mencoba.

Jika situasi yang digambarkan secara 'sekilas itu tak terlalu melenceng, dengan kata lain, maka pertanyaannya adalah apakah persoalan defisit neraca transaksi. berjalan itu bersifat temporer ataukah merupakan persoalan yang lebih bersifat jangka panjang, latent dan struktural ?
Jika jawaban yang kita berikan condong pada kemungkinan yang pertama - temporer dan tidak struktural - maka persoalan NTB itú hanya sekedar persoalan "mismatch" antara aliran kas masuk dan keluar. Tak lebih dari sekedar persoalan akuntansi, yang terjadi sebagai akibat adanya kesenjangan waktu aliran devisa masuk dan keluar. Impor barang modal yang digunakan 'untuk investasi belum menghasilkan devisa yang cukup untuk mengimbangi derasnya pembayaran yang ada pada NJ dan derasnya aliran modal masuk.

Namun demikian, persoalan ini menjadi lebih agak serius, jika kita dipaksa melihat persoalan defisit NTB sebagai perśoalan struktural. Kecurigaan yang demikian bukan tanpa aläsan. Kalau tak ada. "windfall profit" dari Krisis dan Perang Teluk, hampir dapat dipastikan beban defisit. NTB untuk tahun angaran yảng baru lalau akan berskala dua kali lipat. Sementara kita tahu persis bahwa apa yang disebut dengan rejeki "nomplok" itu amat jarang sekali, entah kalau peran polisional dunia yang sekarang sedang. diketahui Amerika Serikat terus berjalan. Yang juga mengkhawatirkan ternyata persoalan "decreasing growth" dari deregulssi ekonomi yang sekarang sedang berjalan ternyata kemudian tersendatsendat.

Jika misalnya pèndapat yang kedua ini yang muncul kepermukaan, bukan tak mungkin kebijaksanaan ekonomi yang cukup drastis akan terpaksa diambil oleh pemerintah. Saat itulah dunia bisnis Indonesia akan mengalami "gonjangganjing". Bagaimana tidak ? Mau tak mau investasi, khususnya investasi yang menggunakan banyak devisa, akan dikurangi. Proyek, apalagi yang mega dan 
meta, hampir dipastikan hilang dari permukaan. Terkena pangkas. Apalagi "white elephant project". Tak terbatas pada pengetahuan likuiditas dalam negeri dengan tight money, policy - tetapi juga pembatasan " off, shore loan" yang dilakukan oleh swasta. Yang paling tidak kita sukai adalah jika terpaksa pemerintah membengkakkan nilai rupiah dengan cara devaluasi, sekalipun untuk kebijaksanaan yang baru disebut terakhir ini memang masih jauh dari kemungkinan.

Oleh karena itu, jika kita hendak optimis maka kita haris meletakan

\begin{tabular}{|c|c|c|c|}
\hline \multicolumn{4}{|c|}{$\begin{array}{c}\text { Lampiran } 1 \\
\text { TRANSAXSI BERJALAN, 1979/80 - 1992/93 } \\
\text { (dolam Juta US\$) }\end{array}$} \\
\hline $\begin{array}{l}\text { Tahuin } \\
\text { anggaran }\end{array}$ & Elspor & $\begin{array}{c}\text { Impordan } \\
\text { josa }\end{array}$ & $\begin{array}{l}\text { Transaksi } \\
\text { berjatan }\end{array}$ \\
\hline (1) & (2) & (3) & (4) \\
\hline 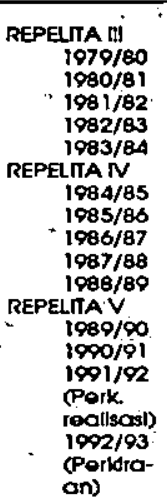 & $\begin{array}{l}18.511 \\
22.885 \\
22.894 \\
18.672 \\
18.816 \\
19.901 \\
18.612 \\
13.697 \\
18.343 \\
19.824 \\
23.830 \\
28.143 \\
29.222 \\
31.791\end{array}$ & $\begin{array}{l}16.313 \\
20.754 \\
25.784 \\
25.711 \\
23.067 \\
\\
21.809 \\
20.444 \\
17.748 \\
20.050 \\
21.683 \\
25.429 \\
31.884 \\
33.621 \\
\\
36.134\end{array}$ & $\begin{array}{c} \\
+2.198 \\
+2.131 \\
-2.790 \\
-7.039 \\
-4.151 \\
-1.968 \\
-1.832 \\
-4.051 \\
-1.707 \\
-1.859 \\
-1.599 \\
-3.741 \\
-4.399 \\
-4.343 \\
.\end{array}$ \\
\hline
\end{tabular}

\section{Catatan :}

Naskah ini diseminarkan sebelum adanya pernyataan pemerintah Indonesia tentang penghentian bantuan Belanda dan penolakan terhadap' Belandin sebagai Kelua IGGI. persoalan NTB pada kategori yang pertama. Hanya temporer. Sekalipun. mungkin ada yang bertanya seberapa lama temporer itu. Namun demikian, apapun jawabnya, nampaknya peran ekonomi Indonesia di ketiga jenis pasar; good, factor, financial markets, perlu diseimbangkan. Lebih penting lagi ditumbuhkan. Untuk keperluan ini deregulasi ekonomi tak boleh ditahan lajunya. Tentu saja dibarengi dengan adanya hukum positip tentang persaingan ekonomi. Bukankah begitu ?.

\begin{tabular}{|c|c|c|c|}
\hline \multicolumn{4}{|c|}{$\begin{array}{c}\text { Lamplian } 2 \\
\text { NERACA PEMBAYARAN INDONESIA } \\
1990 / 91-1992 / 93 \\
\text { (dalam Juta US\$) }\end{array}$} \\
\hline$r$ & (reations) & $\underset{\text { (pont reof) }}{1991 / 20}$ & 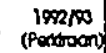 \\
\hline $\bar{r}$ & (1) & (2) & (3) \\
\hline 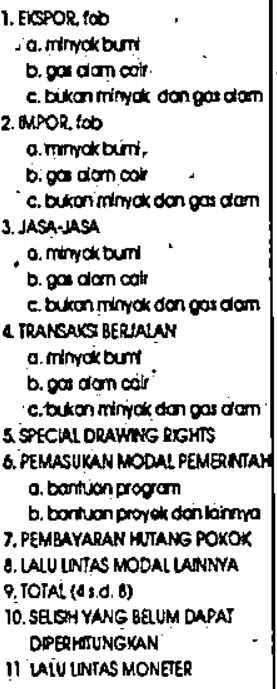 & 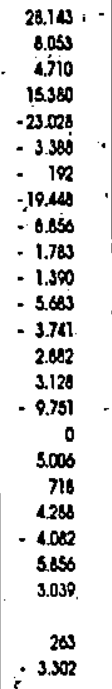 & 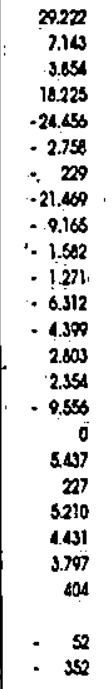 & 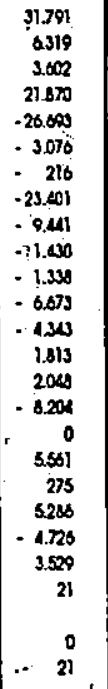 \\
\hline 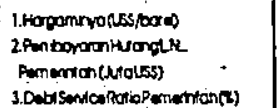 & $\begin{array}{l}2 A B \\
a n 1 \\
20,9\end{array}$ & $\begin{array}{r}1900 \\
705 \\
203\end{array}$ & $\begin{array}{l}151 \\
2151\end{array}$ \\
\hline
\end{tabular}

